\title{
Metode Drill dalam Pembelajaran Pendidikan Agama Islam
}

\author{
SYAHRAINI TAMBAK \\ Fakultas Agama Islam (FAI) Universitas Islam Riau (UIR) Pekanbaru \\ Jl. Kaharuddin Nasution, No. 113, Perhentian Marpoyan Pekanbaru 28284 \\ e-mail: syahraini tambak@yahoo.co.id
}

\begin{abstract}
Abstrak: Banyak metode yang dapat digunakan dalam pembelajaran Pendidikan Agama Islam (PAI). Salah satunya adalah metode drill. Metode drill adalah suatu cara penyajian bahan pelajaran pendidikan agama Islam dengan jalan melatih peserta didik secara berulang-ulang dan sungguh-sungguh dalam bentuk lisan, tulisan, maupun aktivitas fisik agar peserta didik memiliki ketangkasan atau keterampilan yang tinggi dalam menguasai bahan pelajaran, memperkuat suatu asosiasi atau menyempurnakan suatu keterampilan supaya menjadi permanen. Metode drill dapat digunakan baik pada saat mengajarkan kecakapan motoris maupun kecakapan mental. Namun demikian, metode drill ini juga memiliki beberapa kelebihan dan kekurangan. Oleh karenanya, diperlukan langkah-langkah khusus agar penggunaan metode drill ini dapat berjalan dengan efektif sehingga hasil pembelajaran Pendididikan Agama Islam (PAI) dapat mencapai hasil maksimal. Adapun langkah-langkah metode drill tersebut adalah: asosiasi, menyampaikan tujuan yang hendak dicapai, memotivasi peserta didik, melakukan latihan dengan pengulangan secara bertahap, aplikasi, evaluasi dan tindak lanjut.
\end{abstract}

Kata kunci: Metode drill, pembelajaran, Pendidikan Agama Islam

\section{PENDAHULUAN}

Metode pengajaran yang baik adalah metode yang mampu mengantarkan peserta didik dalam berbagai macam kegiatan, dalam hal ini peserta didik harus diberi kesempatan untuk melatih kemampuannya, misalnya menyelesaikan tugas-tugas dan latihan-latihan. Salah satu metode yang digunakan guru dalam pembelajaran Pendidikan Agama Islam (PAI) adalah metode drill atau latihan. Drill atau latihan merupakan metode mengajar yang dapat digunakan untuk mengaktifkan peserta didik pada saat proses belajar mengajar berlangsung, karena metode drill menuntut peserta didik untuk selalu belajar dan mengevaluasi latihan-latihan yang diberikan oleh guru.

Metode drill sering disebut orang sebagai latihan siap dan hal ini menunjukkan bahwa seorang guru PAI harus memperhatikan bagaimana cara melatih peserta didik hingga mereka memiliki kemampuan yang tinggi. Latihan yang harus dipersiapkan oleh guru PAI dalam sebuah metode tidaklah sama dengan latihan yang sering dilakukan guru pada saat akhir pembelajaran. Sebab latihan yang dilakukan pada akhir pembelajaran 
mengarah pada evaluasi hasil belajar peserta didik. Inilah hal penting yang harus diperhatikan oleh guru PAI dalam menjalakan metode drill tersebut untuk mencapai pembelajaran yang maksimal.

Apabila guru PAI ingin menggunakan metode drill ini dalam pembelajaran bidang studi Pendidikan Agama Islam (PAI) maka haruslah betul-betul memperhatikan langkah demi langkah dalam desainnya. Sebab tak jarang seorang guru lalai dalam memperhatikan langkah-langkah penggunaan sebuah metode pembelajaran. Guru PAI jangan lagi mengajar dengan menggunakan sebuah metode sesuai dengan seleranya saja, akan tetapi mulailah bergerak dengan melakukan eksplorasi dan memperhatikan langah-langkah penggunaan sebuah metode, termasuk dalam hal ini metode drill.

\section{PENGERTIAN METODE DRILL}

Metode drill menurut Ramayulis disebut latihan siap dimaksudkan untuk memperoleh ketangkasan atau keterampilan latihan terhadap apa yang dipelajari, karena hanya dengan melakukan secara praktis suatu pengetahuan dapat disempurnakan dan siapsiagakan (Ramayulis, 2010: 349). Pendapat ini menggambarkan bahwa metode drill tersebut menekankan pada pembelajaran yang bersifat latihan siap untuk keterampilan. Pembelajaran yang dilangsungkan untuk metode ini dimana materi yang akan diajarkan menuntut untuk pada sebuah penguasaan keterampilan peserta didik agar mereka memiliki ketangkasan yang langsung dapat siap dalam pengetahuan diri sendiri.

Sementara

Roestiyah

mengungkapkan bahwa metode drill adalah suatu cara mengajar di mana peserta didik melaksanakan kegiatankegiatan latihan, peserta didik memiliki ketangkasan atau keterampilan yang lebih tinggi dari apa yang telah dipelajari (Roestiyah, 1985: 125). Pendapat ini menggambarkan bahwa metode drill tersebut menekankan pada cara mengajar guru dalam melaksanakan latihan-latihan pada peserta didik untuk memperoleh ketangkasan yang lebih tinggi dibanding sebelumnya. Di sini tampak bahwa metode drill menginginkan adanya proses pembelajaran di mana terjadi pengerjaan latihan pembelajaran yang dilakukan oleh peserta didik untuk mencapai tingkat ketangkasan pengetahuan peserta didik.

Zuhairini, et. al. (1983: 106) mengatakan bahwa metode drill adalah suatu metode dalam pendidikan dan pengajaran dengan jalan melatih anakanak terhadap bahan pelajaran yang sudah diberikan. Pendapat ini lebih sederhana di bandingkan pendapat sebelumnya, di mana metode drill tersebut secara spesifik merupakan cara mengajar guru dengan melatih peserta didik terhadap bahan yang telah disampaikan oleh guru. Namun pendapat ini memiliki kelamahan karena bila bahan yang telah diberikan atau diajarkan oleh guru dilakukan latihan-latihan oleh peserta didik, apakah ini tidak termasuk dengan evaluasi pembelajaran.

Salahuddin mengatakan bahwa metode drill adalah suatu kegiatan dalam melakukan hal yang sama secara berulang-ulang dan sungguh-sungguh dengan tujuan untuk memperkuat suatu asosiasi atau menyempurnakan suatu keterampilan supaya menjadi permanen (1987: 100). Menurut Syaiful Sagala, metode drill adalah metode latihan, atau metode training yang merupakan suatu cara mengajar yang baik untuk menanamkan kebiasaankebiasaan tertentu. Juga sebagai sarana untuk memperoleh suatu ketangkasan, ketepatan, kesempatan dan 
keterampilan (Sagala, 2009: 21). Seorang guru perlu menerapkan metode ini untuk membiasakan anakanak sesuai dengan tujuan-tujuan tertentu dalam pembelajaran. Metode ini juga dapat dijadikan sebuah acuan, bagi seorang guru dalam meningkatkan hasil belajar peserta didik, latihanlatihan biasanya juga dalam bentuk tes tertulis yang dapat dianalisis hasilnya berupa angka-angka, untuk mendapatkan sebuah kesimpulan berhasil atau tidaknya sebuah pengajaran yang telah dilaksanakan.

Metode drill merupakan suatu metode yang memberikan kesempatan kepada peserta didik untuk melatih melakukan sesuatu keterampilan tertentu berdasarkan penjelasan atau petunjuk guru. Ciri khas dari metode ini adalah kegiatan yang berupa pengulangan yang berkali-kali supaya asosiasi stimulus dan respons menjadi sangat kuat dan tidak mudah untuk dilupakan. Dengan demikian terbentuklah sebuah keterampilan (pengetahuan) yang setiap saat siap untuk dipergunakan oleh yang bersangkutan (Shaleh, 2006: 203). Dengan demikian metode drill ini bermaksud memberikan pengetahuan dan kecakapan tertentu yang dapat menjadi milik anak didik dan dikuasainya dengan baik, bukan hanya bertujuan untuk pengukuran semata.

Berdasarkan beberapa pendapat di atas dapat penulis tegas di sini bahwa yang dimaksud dengan metode drill dalam pendidikan agama Islam adalah "suatu cara penyajian bahan pelajaran pendidikan agama Islam dengan jalan melatih peserta didik secara berulang-ulang dan sungguhsungguh dalam bentuk lisan, tulisan, maupun aktivitas fisik agar peserta didik memiliki ketangkasan atau keterampilan yang tinggi dalam menguasai bahan pelajaran, memperkuat suatu asosiasi atau menyempurnakan

suatu

keterampilan supaya menjadi permanen".

Maka, di sini hal yang perlu ditekankan bagi seorang guru atau calon guru PAI adalah bahwa penyajian pelajaran PAI dengan menggunakan metode drill ini hanya dilakukan di dalam kelas bukan di luar kelas dan tidaklah sekedar hanya mengulangulang pelajaran yang telah disampaikan saja. Akan tetapi proses pengulangan di sini adalah materi yang disampaikan tersebut diajarkan dengan berulangulang agar peserta didik dapat memahaminya dengan baik dan memiliki asosiasi yang tinggi.

Sebagai contoh dalam hal ini adalah seorang guru PAI akan mengajarkan materi tentang al-Qur'an di mana peserta didik akan menghafal sebuah ayat lengkap dengan artinya. Maka metode drill sangat tepat diberikan dengan cara guru mengucapkan terlebih dahulu penggalan ayat-ayat dan peserta didik mengikutinya baik secara individu, berkelompok mapun klasikal dilakukan secara berulang-ulang hingga peserta didik memiliki asosiasi dan keterampilan. Pengulangan penggalan ayat tersebut dapat dilakukan lebih dari tiga kali dan diikuti oleh peserta didik higga guru PAI menganggap bahwa mereka para peserta didik sudah dapat menguasai bahan tersebut. Setelah peserta didik menguasai satu penggalan ayat berikut artinya tersebut lalu kemudian melanjutkan pada penggalan ayat berikutnya, demikian selanjutnya dilakukan secara berulang-ulang.

Secara spesifik ada beberapa hal yang perlu diperhatikan dari metode drill ini dalam pembelajaran pendidikan agama Islam (PAI), yaitu: Pertama, cara penyajian bahan pelajaran pendidikan agama Islam dengan jalan melatih peserta didik secara berulang-ulang dan sungguh-

Jurnal Al-hikmah Vol. 13, No. 2, Oktober 2016 ISSN 1412-5382 
sungguh. Latihan yang dilakukan guru PAI dengan cara berulang-ulang ini menunjukkan sebuah proses bahwa materi yang diajarkan dapat dipahami oleh peserta didik dengan jalan latihan yang dilakukannya secara berulangulang.

Kedua, dalam bentuk lisan, tulisan, maupun aktivitas fisik. Latihan berulang-ulang tersebut di atas yang dilakukan oleh guru dapat dilaksanakan dalam bentuk lisan, tulisan, maupun aktivitas fisik. Latihan berulang-ulang dengan lisan dapat dilakukan oleh guru PAI dengan mengeluarkan suaranya untuk mengucapkan sebuah kata atau apapun itu di depan kelas, lalu peserta didik mengikutinya, hingga mereka dapat memiliki pemahaman dan asosiasi terhadap materi yang diajarkan.

\begin{tabular}{llr}
\multicolumn{1}{c}{ Ketiga, agar peserta didik } \\
memiliki & $\begin{array}{r}\text { ketangkasan } \\
\text { atau }\end{array}$ \\
keterampilan yang tinggi dalam \\
menguasai
\end{tabular} $\begin{array}{lr}\text { bahan pelajaran, } \\
\text { memperkuat suatu asosiasi atau } \\
\text { menyempurnakan }\end{array}$
tujuan dari penggunaan metode drill tersebut di mana peserta didik memiliki ketangkasan, keterampilan, dan memiliki asosiasi supaya dapat pengetahuan tersebut menjadi dapat diketahui secara permanen oleh peserta didik. Di sini berarti seorang guru PAI harus menggunakan metode drill tersebut dalam capaian akhir bahwa materi yang diajarkan dapat dipahami dan kuasai oleh peserta didik hingga menjadi sebuah ilmu yang dapat dikuasainya.

Dalam proses pembelajaran PAI sesungguhnya metode drill diarahkan untuk melatih ketrampilan baik fisik maupun mental, karena hanya dengan latihan suatu ketrampilan dapat dikuasai. Latihan berhubungan dengan pembentukan kemahiran atau kecakapan. Tujuan metode drill adalah untuk memperoleh suatu ketangkasan, keterampilan tentang sesuatu yang dipelajari anak dengan melakukannya secara praktis pengetahuanpengetahuan yang dipelajari anak itu. Secara spesifik metode drill (latihan siap) ini biasanya dipergunakan untuk tujuan agar peserta didik: Pertama, memiliki keterampilan motoris/gerak, seperti menghafal kata-kata, menulis, mempergunakan alat atau membuat suatu benda; melaksanakan gerak dalam olah raga. Kedua, mengembangkan kecakapan intelektual, seperti mengalikan, membagi, menjumlahkan, mengurangi, menarik akar dalam hitungan mencongak. Mengenal benda/bentuk dalam pelajaran matematika, ilmu pasti, ilmu kimia, tanda baca dan sebagainya. Ketiga, memiliki kemampuan menghubungkan antara sesuatu keadaan dengan hal lain, seperti sebab akibat banjir-hujan; antara tanda huruf dan bunyi -ing, ny dan lain sebagainya; penggunaan lambang/simbol di dalam peta dan lain (Roestiyah, 1985: 79).

\section{DASAR METODE DRILL DALAM AL- QUR'AN}

Metode drill yang sebenarnya menunjuk kepada hal itu secara riil tidaklah ditemukan secara lebih rinci dalam al-Qur'an. Namun bila ditelusuri makna dari metode tersebut akan ditemukan secara subtantif. Metode drill bersumber dari al-Qur'an dan landasan yang dipakai untuk metode ini dapat dipahami dari ayat yang berbunyi:

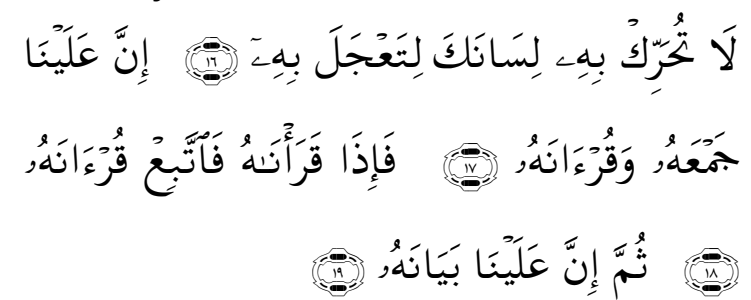


Artinya: "Janganlah kamu gerakkan lidahmu untuk (membaca) Al Quran karena hendak cepat-cepat (menguasai)nya. Sesungguhnya atas tanggungan Kamilah mengumpulkannya (di dadamu) dan (membuatmu pandai) membacanya. Apabila Kami telah selesai membacakannya maka ikutilah bacaannya itu. Kemudian, Sesungguhnya atas tanggungan kamilah penjelasannya". (QS. Al-Qiyamah, 75: 17-18).

Ayat di atas bagaikan menyatakan: Janganlah engkau, wahai Nabi Muhammad, menggerakkan dengannya, yakni menyangkut al-Qur'an, lidahmu untuk membacanya sebelum malaikat Jibril selesai membacakannya kepadamu karena engkau hendak mempercepat menguasai bacaan-nya takut jangan sampai engkau tidak menghafalnya atau melupakan salah satu bagian darinya (Shihab, 2012: 539). Berdasarkan makna ini dapat diinterpretasi bahwa dalam menggunakan metode drill di mana ada proses latihan yang dilakukan secara berulang-ulang hendaknya dilakasanakan dalam proses pembelajaran tidak terburu-buru. Proses latihan yang dilaksanakan secara berulang tersebut haruslah memperhatikan secara lebih jelas apa yang disampaikan oleh guru dalam proses pembelajaran.

Sesungguhnya atas tanggungan Kami-lah pengumpulannya sehingga sempurna ucapan katanya tanpa harus mendahului Jibril dalam pengucapannya atau pengumpulannya di dalam dadamu dan engkau mampu menghafalnya tanpa bersusah payah dan atas tanggungan Kami pula pembacaannya sehingga engkau pandai dan lancar membacanya. Jika demikian, maka apabila Kami-melalui malaikat Jibril-telah selesai membacakannya kepadamu, maka ikutilah dengan lidah, pendengaran hati, serta pikiranmu secara sungguh-sungguh, atau ikutilah dengan pengamalan pesan bacaannya, yakni bacaan Jibril atau bacaan alQur'an itu. Kemudian, sesungguhnya atas tanggungan Kami-lah penjelasan, makna-makna-nya (Shihab, 2012: 541542).

Kata yang menggambarkan makna metode drill dalam pembelajaran PAI dari ayat di atas adalah faiza qara'nahu fattabi' qur'anahu artinya apabila telah selesai Kami membacakannya maka ikutilah bacaannya itu. Penekanan kata di sini adalah kata faiza qara'nahu fattabi' qur'anahu/maka apabila telah Kami selesai membacakannya, maka ikutilah bacaannya. Di sini terdapat proses pelatihan yang diberikan oleh Malaikat Jibril pada Nabi Muhammad SAW untuk mengulangi apa yang telah dibacakan. Mengulangi apa yang dibacakan menggambarkan adanya "latihan yang dilakukan secara berulang-ulang" yang harus dilaksanakan agar lebih dapat memahami dengan baik. Al-Maraghi (t.t. : 150) menafsirkan potongan ayat tersebut di atas sebagai berikut:

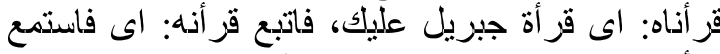

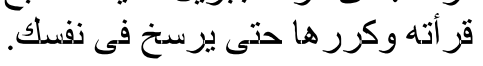

Qara'nahu dimaksudkan adalah Jibril membacakannya kepadamu fattabi' qur'anah maksudnya maka dengarkanlah bacaan dan ulangulangilah agar ia mantap dalam dirimu. Ayat tersebut merupakan bentuk metode pembelajaran al-Qur'an ketika Malaikat Jibril memberikan wahyu (alQur'an) kepada Nabi Muhammad SAW dengan membacakannya, maka Nabi Muhammad SAW diperintahkan untuk mengulanginya, sehingga Nabi Muhammad SAW hafal dan bacaan tersebut dapat membekas dalam dirinya.

\section{KONDISI PENGGUNAAN}

, Oktober 2016 ISSN 1412-5382 
Berdasarkan pengertian metode drill yang telah penulis kemukakan sebelumnya bahwa drill merupakan suatu cara mengajar dengan memberikan latihan-latihan terhadap apa yang telah dipelajari peserta didik sehingga memperoleh suatu keterampilan tertentu. Ada keterampilan yang dapat disempurnakan dalam jangka waktu yang pendek dan ada yang membutuhkan waktu cukup lama. Perlu diperhatikan latihan itu tidak diberikan begitu saja kepada peserta didik tanpa pengertian, jadi latihan itu didahului dengan pengertian dasar. Metode drill wajar digunakan untuk:

\section{Disaat Mengajarkan Kecakapan Motoris}

Metode drill tidaklah secara serta merta dapat digunakan untuk semua jenis dan karakter materi pembelajaran, akan tetapi dapat dipergunakan untuk kecakapan motoris. Kecakapan motoris secara sederhana merupakan kemampuan seorang peserta didik dalam hal menggunakan seluruh aspek tubuh yang dimilikinya dalam mengolah sesuatu. Kecakapan motoris ini dapat dilihat berupa kecakapan menggunakan alat-alat musik, olahraga, menari, pertukangan, menulis, menggambar, permainan, membuat grafik, dan seluruh kegiatan yang membutuhkan penggunaan fisik.

\section{Disaat Mengajarkan Kecakapan Mental}

Kecakapan mental merupakan kemampuan yang signifikaan yang dimiliki oleh sesorang berkaitan dengan aspek psikis. Kecakapan aspek ini secara material kurang dapat dilihat dalam diri inidividu namun akan tampak pada saat melakukan sesuatu. Kecakapan mental ini dapat dilhat misalnya menghafal, menjumlah, mengalikan, membagi dan sebagainya. Terkait dengan hal di atas ada beberapa hal yang perlu diperhatikan dalam proses penggunaan metode drill, yaitu; (1) Tujuan harus dijelaskan kepada peserta didik sehingga selesai latihan mereka diharapkan dapat mengerjakan dengan tepat sesuai apa yang diharapkan; (2) Tentukan dengan jelas kebiasaan yang dilatihkan sehingga peserta didik mengetahui apa yang harus dikerjakan; (3) Lama latihan harus disesuaikan dengan kemampuan peserta didik; (4) Selingilah latihan agar tidak membosankan; (5) Perhatikan kesalahan-kesalahan umum yang dilakukan peserta didik untuk perbaikan secara kiasikal sedangkan kesalahan perorangan dibetulkan secara perorangan pula.

\section{KELEBIHAN DAN KEKURANGAN METODE DRILL Kelebihan Metode Drill}

Terdapat beberapa hal yang perlu diperhatikan oleh guru PAI dalam proses penggunaan metode drill tersebut yang dilihat dari aspek kelebihan. Kelebihan ini sekaligus sebagai kekuatan yang perlu diperhatikan dalam penggunaan metode drill. Kelebihan metode drill adalah sebagai berikut:

Pertama, pengertian peserta didik lebih luas melalui latihan berulangulang. Kelabihan ini menggambarkan bahwa dengan penggunaan metode drill peserta didik dalam mengikuti pembelajaran PAI akan memiliki pengertian lebih luas karena latihan yang dilakukan dengan berulang. Tentu bila materi yang diajarkan seorang guru PAI dilakukan secara berulang-ulang akan membuat pemahaman peserta didik lebih luas dan tepat.

Kedua, peserta didik siap menggunakan keterampilannya karena 
sudah dibiasakan. Metode drill yang dilaksanakan oleh guru PAI membuat ketarampilan para peserta didik lebih siap dia pergunakan. Bila pengetahuan terkait dengan aktivitas fisik yang menuntut pada suatu keterampilan, maka harus dikuasai latihan tertentu yang dilakukan secara berulang-ulang akan lebih mudah dikuasai dibanding dengan pembelajaran yang bersifat verabalistik semata.

Ketiga, peserta didik memperoleh kecakapan motoris. Salah satu aspek penting yang perlu diperhatikan oleh guru PAI dalam penggunaan metode drill ini adalah adanya kecakapan motoris yang dimiliki dan dukuasai oleh peserta didik. Kecakapan motoris sangatlah penting dimiliki oleh para peserta didik karena hal itu dapat dilihat realitasnya tanpa ada permainan penilaian yang kurang tepat. Ukuran kecakapan motoris hanyalah pada dua hal saja, yaitu bisa atau tidak bisa saja. Maka dengan penggunaan metode drill hal ini dapat dilakukan dengan jelas, dan pengetahuan peserta didik pun dapat diukur dengan jelas pula. Hal yang dapat dilihat dari kecakapan motorik yang diperoleh peserta didik adalah menulis, melafalkan huruf, membuat dan menggunakan alat-alat.

$\begin{array}{cr}\text { Keempat, } & \text { peserta didik } \\ \text { memperoleh } & \text { kecakapan mental. }\end{array}$

Kecakapan mental sangat penting artinya bagi peserta didik dalam proses perkembangan dirinya menjadi manusia terpelajar dan sukses di masa depan. Penggunaan metode drill dalam kaitan ini dapat membina kecakapan mental peserta didik hingga pengetahuannya dapat member dampak yang besar dalam hidupnya. Terkati dengan hal ini dapat dilihat dalam perkalian, penjumlahan, pengurangan, pembagian, tandatanda/simbol, dan sebagainya.

$$
\text { Kelima, dapat membentuk }
$$

kebiasaan dan menambah ketepatan dan kecepatan pelaksanaan. Dengan adanya latihan yang dilakukan secara berulang-ulang tentang sebuah materi pembelajaran maka akan membuat hal itu menjadi kebiasaan dan sekaligus menambah ketetapan dan kecepatan pelaksanaa.

Keenam, peserta didik memperoleh ketangkasan dan kemahiran dalam melakukan sesuatu sesuai dengan yang dipelajarinya. Ketangkasan dan kemahiran dalam melakukan sesuatu akan muncul setelah materi pembelajaran dilakukan dengan latihan yang berulang-ulang.

Ketujuh, dapat menimbulkan rasa percaya diri bahwa peserta didik yang berhasil dalam belajar telah memiliki suatu keterampilan khusus yang berguna kelak dikemudian hari. Rasa percaya diri menjadi bagian penting yang harus dimiliki oleh peserta didik, sebab tak jarang para peserta didik memiliki rasa percaya diri yang kurang. Melalui penggunaan metode drill ini kepercayaan diri peserta didik akan meningkat karena telah memiliki keterampilan yang memang dikuasai.

Kedelapan, guru lebih mudah mengontrol dan membedakan mana peserta didik yang disiplin dalam belajarnya dan mana yang kurang dengan memperhatikan tindakan dan perbuatan peserta didik saat berlangsungnya pengajaran. Melalui penggunaan metode drill dalam pembalajaran PAI seorang guru PAI akan lebih mudah mengontrol peserta didik yang disiplin dengan melihat tindakan atau perbuatan peserta didik itu sendiri.

Kesembilan, menghindarkan ketegangan. Metode driil yang dilakukan oleh guru PAI dapat menghindarkan ketegangan peserta didik. Menurut Muntasir seperti dikutip Akbarizan, penggunaan metode drill dalam pembelajaran dapat menghindarkan ketegangan dan 
suasana yang menakutkan pada anak didik dengan menggunakan pelatihanpelatihan yang intensif, memberikan contoh tingkah laku yang baik, partisipasi yang memadai pada anak didik, serta memandang bahwa segala aktivitas yang dilakukan merupakan ibadah (Akbarizan, 2008: 53-54).

\section{Kelemahan Metode Drill}

Di samping kelebihan yang telah diuraikan di atas, terdapat pula beberapa kelemahan dan sekaligus hal ini menjadi perhatian yang perlu dihindari oleh guru PAI dalam proses pembelajaran pendidikan agama Islam, dapat lihat dalam uraian berikut.

Pertama, peserta didik cenderung belajar secara mekanis. Disebabkan matode ini dengan penggunaan latihan yang berulang-ulang maka peserta didik dalam pembelajarannya cenderung seperti mekanis. Hal dikarenakan peserta didik hanyalah mengikuti pembelajaran sesuai dengan teori-teori yang ada. Membentuk kebiasaan yang kaku. Kebiasaan yang kaku artinya seolah-olah peserta didik melakukan sesuatu secara mekanis, dalam dalam memberikan stimulus peserta didik bertindak secara otomatis.

Kedua, dapat menyebabkan

kebosanan. Penggunaan metode drill bila kurang dapat dikuasai oleh guru PAI akan membuat peserta didik merasa bosan dalam pembelajaran, karena bentuknya hanya itu-itu saja.

Ketiga, dapat mematikan kreasi peserta didik. Penggunaan metode dengan drill bagi guru yang kurang mampu dapat membuat peserta didik kurang senang karena drill hanya akan mengulangi pelajaran dengan tugastugas yang telah ditentukan oleh guru. Peserta didik kurang dapat mengembangkan kreativitasnya akibat dari bentuk pembelajaran atau materi yang diajarkan hanya dapat dilakukan dengan latihan saja.

Keempat, menimbulkan verbalisme. Metode drill yang dipergunakan dalam pembelajaran PAI dapat saja membuat peserta didik cenderung bersikap verbalisme. Bersikap verbalisme dalam makna peserta didik mengetahui kata-kata atau secara lisan akan tetapi tidak mengetahui makna atau arti dari pelajaran yang diterimanya. Kekurangan metode ini dapat menimbulkan verbalisme, terutama pengajaran yang bersifat menghafal. Di mana peserta didik dilatih untuk dapat menguasai bahan pelajaran secara hafalan dan secara otomatis mengingatkannya bila ada pertanyaan yang berkenaan dengan hafalan tersebut tanpa suatu proses berfikir secara logis.

Kelima, menimbulkan penyesuaian secara statis kepada lingkungan. Proses pembelajaran yang sesungguhnya adalah terjadinya penyesuaian diri dengan lingkungannya secara alamiah dan baik. Tugas-tugas yang dilakukan hanya mengikuti aturan dari perintah guru PAI dimana peserta didik menyelesaikan tugas secara statis sesuai dengan apa yang diinginkan oleh guru.

\section{DESAIN METODE DRILL DALAM PEMBELAJARAN PAI}

Seorang guru PAI, apabila ingin sukses dalam proses pembelajarannya dalam menggunakan metode drill haruslah memperhatikan desain metode drill tersebut. Tampak sekilas dari aspek literal, metode drill ini sangatlah mudah diterapkan oleh guru dalam mengajar. Akan tetapi bila melihat pada penggunaan dan aplikasi setiap metode tak jarang guru PAI merasa kesulitan karena kurang mengetahui langkah-langkah atau 
desain dari sebuah metode tersebut. Oleh karena itu, suatu hal yang tak dapat diabaikan oleh siapapun yang akan menjadi guru dalam mengajarkan bidang studi PAI tetaplah diharuskan untuk mempelajari dan menjalankan pembelajarannya dengan mengikuti desain metode drill tersebut. Untuk memperjelas hal ini dapat dilihat desain metode drill dalam pembelajaran PAI berikut ini:

Gambar: 1

Siklus Metode Drill dalam Pembelajaran Pendidikan Agama Islam

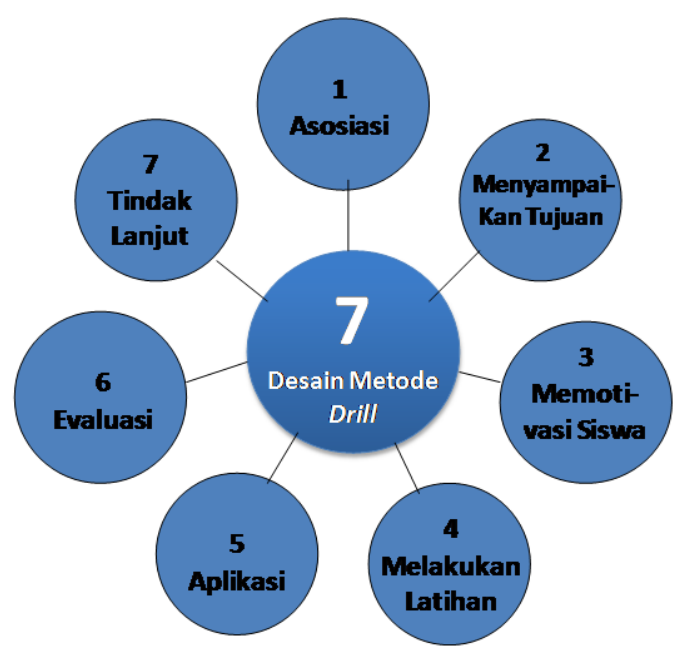

\section{Asosiasi}

Langkah pertama yang harus dilakukan oleh guru dalam proses penggunaan metode drill dalam pembelajaran PAI adalah guru memberikan gambaran antara materi yang akan dipelajari dengan pengetahuan yang sudah di miliki oleh peserta didik tersebut. Pemberian gambaran pengetahuan ini sangat penting di mana guru PAI harus sudah mengetahui bagaimana pengetahuan yang dimiliki oleh peserta didik sebelumnya terhadap materi yang akan diajarakan berkut tersebut.

Dalam psikologi dan pemasaran, asosiasi dianggap bahwa terdapat dua konsep atau rangsangan yang saling terkait ketika pengalaman yang satu mengarah ke efek lain, karena adanya pasangan berulang atau kawin. Hal ini kadang-kadang disebut Pavlov asosiasi yang diambil dari nama Ivan Pavlov, pelopor dalam studi pengkondisian klasik. Asosiasi adalah suatu prosedur yang digunakan sebagai alat memori. Dengan menghubungkan ide baru (suatu objek, gambar, bau atau apa pun yang seseorang ingin mengingat) dengan yang lain, lebih mudah untuk mengingat keduanya.

Dalam psikologi, asosiasi mengacu pada hubungan antara entitas konseptual yaitu hubungan antara obyek, perasaan dan ide-ide. Otak manusia terdiri dari jaringan saraf yang besar, jaringan ini merupakan dasar dari mana beberapa model fungsi memori telah diusulkan. Memori tampaknya terstruktur sebagai jaringan 
asosiatif yang bertugas menginformasikan tentang hubungan antara hal-hal yang berbeda. Sedangkan Asosiasi dalam psikoanalisis adalah adanya asumsi bahwa terdapat wawasan/ pembelajaran sederhana, yang melibatkan elemen yang direduksikan (biasanya sensorik) sehingga dapat dihubungkan satu sama lain dalam kondisi tertentu.

Asosiasi peserta didik dalam pembelajaran dapat berjalan dan dilakukan oleh peserta didik dalam dua hal. Pertama, ingatan/memori. Asosiasi penting dalam fungsi otak. Memori beroperasi sebagai rantai konseptual, konsep, kata-kata dan ide-ide yang saling terkait. Hubungannya terdapat antara benda-benda, seperti wajah seseorang, dan nama yang terkait dengan wajah. Memahami hubungan antara item yang berbeda adalah dasar memori episodik dan kerusakan wilayah hippocampus otak telah ditemukan untuk menghambat belajar asosiasi antara objek.

Kedua, operant conditioning. Operant conditioning adalah pembelajaran asosiatif eksplisit: asosiasi positif terbentuk ketika dihargai setelah menyelesaikan tugas, dan negatif ketika dihukum setelah selesai tugas. Pada dasarnya pujian akan mendorong seseorang untuk terus melakukan tugas, sementara hukuman akan memberikan keputusaan. Seperti pengkondisian klasik, efek pemberian hadiah menciptakan asosiasi positif terhadap tugas itu sendiri: setelah pelatihan, tugas akan dilihat positif atau negatif tanpa perlu hukuman atau pujian.

Pada tahap ini, terdapat hal-hal penting yang harus dilakukan oleh guru PAI dalam proses pembelajaran, yaitu; (1) guru PAI menghubungkan pembelajaran sebelumnya yang telah dipelajari pada pembelajaran yang akan dipelajari; (2) guru PAI meminta satu atau dua orang peserta didik untuk memberikan komentar terkait materi yang akan dipelajari; dan (3) guru PAI mengajak peserta didik untuk berpikir terkait pembelajaran yang akan dilaksanakan secara singkat hingga peserta didik terbuka penalaran dan intuisinya.

\section{Menyampaikan Tujuan yang Hendak Dicapai}

Menyampaikan tujuan pembelajaran terkadang sering terabaikan oleh guru PAI dalam setiap pembelajarannya, padahal hal itu sangatlah penting untuk memberikan gambaran pada peserta didik ke mana arah mereka dalam pembelajaran tersebut. Oleh karena itu agar pembelajaran dapat berjalan dengan lancar maka guru PAI harus menyampaikan tujuan dari pembelajaran tersebut.

Tujuan pembelajaran adalah tercapainya perubahan perilaku atau kompetensi pada peserta didik setelah mengikuti kegiatan pembelajaran tercapainya perubahan perilaku atau kompetensi pada peserta didik setelah mengikuti kegiatan pembelajaran. Tujuan tersebut dirumuskan dalam bentuk pernyataan atau deskripsi yang spesifik. Upaya merumuskan tujuan pembelajaran dapat memberikan manfaat tertentu, baik bagi guru maupun peserta didik. Nana Syaodih Sukmadinata (2002) mengidentifikasi 4 (empat) manfaat dari tujuan pembelajaran, yaitu: (1) memudahkan dalam mengkomunikasikan maksud kegiatan belajar mengajar kepada peserta didik, sehingga peserta didik dapat melakukan perbuatan belajarnya secara lebih mandiri; (2) memudahkan guru memilih dan menyusun bahan ajar; (3) membantu memudahkan guru menentukan kegiatan belajar dan media 
pembelajaran; (4) memudahkan guru mengadakan penilaian.

Kegiatan menyusun rencana pembelajaran merupakan salah satu tugas penting guru dalam memproses pembelajaran peserta didik. Dalam perspektif kebijakan pendidikan nasional yang dituangkan dalam Permendiknas RI No. 52 Tahun 2008 tentang Standar Proses disebutkan bahwa salah satu komponen dalam penyusunan Rencana Pelaksanaan Pembelajaran (RPP) yaitu adanya tujuan pembelajaran yang di dalamnya menggambarkan proses dan hasil belajar yang diharapkan dapat dicapai oleh peserta didik sesuai dengan kompetensi dasar.

Salah satu sumbangan terbesar dari aliran psikologi behaviorisme terhadap pembelajaran bahwa pembelajaran seyogianya memiliki tujuan. Gagasan perlunya tujuan dalam pembelajaran pertama kali dikemukakan oleh B.F. Skinner pada tahun 1950. Kemudian diikuti oleh Robert Mager pada tahun 1962 kemudian sejak pada tahun 1970 hingga sekarang penerapannya semakin meluas hampir di seluruh lembaga pendidikan di dunia, termasuk di Indonesia.

Merujuk pada tulisan Hamzah B. Uno berikut ini dikemukakan beberapa pengertian yang dikemukakan oleh para ahli. Robert F. Mager (1962) mengemukakan bahwa tujuan pembelajaran adalah perilaku yang hendak dicapai atau yang dapat dikerjakan oleh peserta didik pada kondisi dan tingkat kompetensi tertentu. Kemp (1977) dan David E. Kapel (1981) menyebutkan bahwa tujuan pembelajaran suatu pernyataan yang spesifik yang dinyatakan dalam perilaku atau penampilan yang diwujudkan dalam bentuk tulisan untuk menggambarkan hasil belajar yang diharapkan. Henry Ellington (1984) bahwa tujuan pembelajaran adalah pernyataan yang diharapkan dapat dicapai sebagai hasil belajar.

Teknik yang dapat dipergunakan guru PAI dalam hal ini adalah; (1) Menanyakan kepada peserta didik pembelajaran yang telah lalu; (2) Menyampaikan secara gamblang tujuan pembelajaran dengan metode drill tersebut. (3) Menyampaikan arti dan manfaat tujuan pembelajaran tersebut bagi peserta didik. Langkah-langkah pelaksanaan metode drill dalam pembelajaran PAI terdapat beberapa teknik yang perlu diperhatikan dan dilalui oleh guru PAI. Sebelum latihan dilaksanakan, peserta didik harus diberi penjelasan mengenai arti atau manfaat dan tujuan dari latihan tersebut.

\section{Memotivasi Peserta Didik}

Memotivasi peserta didik menjadi bagian terpenting dalam proses pembelajaran, karena dari sinilah awal pembelajaran dapat diikuti oleh peserta didik yang kemudian nantinya berdampak pada penguasaan peserta didik terhadap materi pembelajaran yang diajarkan.

Guru PAI yang baik dapat menerapkan metode positif untuk memotivasi peserta didik, sehingga mereka merasa bersemangat untuk belajar dan merasa dihargai, mau bekerja giat, mengikuti peraturan, terus tinggal dan menyelesaikan pendidikan dasarnya serta mempelajari nilai-nilai positif dan keterampilan hidup. Tidak ada formula ajaib untuk memotivasi peserta didik. Banyak faktor yang mempengaruhi motivasi peserta didik untuk bekerja dan belajar. Ketertarikan pada mata pelajaran, persepsi tentang manfaat yang diperoleh, keinginan untuk berprestasi, rasa percaya diri, gender, status sosio-ekonomi serta kesabaran dan ketekunan. Tentunya tidak semua peserta didik termotivasi 
oleh hal yang sama dan tidak memungkinkan untuk membahas keseluruhan aspek motivasi tersebut dalam bagian ini.

Namun, apapun metode yang digunakan untuk memotivasi peserta didik, tetap ada kemungkinan beberapa peserta didik di kelas yang menunjukkan perilaku yang mengganggu proses belajar sehingga penting bagi guru PAI untuk mempelajari juga cara-cara yang efektif untuk mengatur peserta didik tanpa perlu bersikap tidak ramah dan agresif. Dalam mendorong keberhasilan mewujudkan tujuan belajar, motivasi merupakan penentu yang sangat penting, bagaikan bensin yang dapat menggerakan mesin mobil menuju tempat tujuannya. Bagitulah arti penting motivasi, karena motivasi tersebut sebagai keadaan internal yang menyebabkan kita bertindak, mendorong kita pada arah tertentu, dan menjaga kita tetap bersemangat pada aktivitas tertentu. Motivasi membantu peserta didik cepat memahami pelajaran secara lebih baik sehingga mampu meraih tujuan belajar.

Motivasi menurut Syaiful Bahri Djamarah adalah gejala psikologis dalam bentuk dorongan yang timbul pada diri seseorang sadar atau tidak sadar untuk melakukan suatu tindakan dengan tujuan tertentu. Motivasi juga bisa dalam bentuk usaha-usaha yang dapat menyebabkan seseorang atau kelompok orang tertentu tergerak melakukan sesuatu karena ingin mencapai tujuan yang dikehendakinya atau mendapat kepuasan dengan perbuatannya (Djamarah, 2008: 152). Sedangkan menurut Mc. Donald, dalam Sardiman A.M, motivasi adalah perubahan energi dalam diri seseorang yang ditandai dengan munculnya "feeling" dan didahului dengan tanggapan terhadap adanya tujuan (Sardiman, 2011: 73).
Motivasi memegang peran yang sangat penting dalam belajar, apabila tidak ada motivasi dalam belajar, maka tidak ada belajar dalam arti sebenarnya (Dimyati \& Mudjiono, 2009: 80). Di samping itu, hasil belajar peserta didik juga tidak akan sesuai dengan apa yang diharapkan, karena motivasi belajar merupakan salah satu faktor yang mempengaruhi hasil belajar.

WS Winkel dan M.M. Sri Hastuti mengungkapkan bahwa dalam kegiatan belajar, proses pelaksanaannya langsung dan keberhasilannya bukan hanya ditentukan oleh faktor intelektual, tetapi juga faktor-faktor yang non-intelektual, termasuk salah satunya ialah motivasi. Oleh karena itu, motivasi belajar dapat diartikan sebagai keseluruhan daya penggerak psikis dalam diri peserta didik yang menimbulkan kegiatan belajar, menjamin kelangsungan kegiatan belajar itu demi tercapainya suatu tujuan (Winkel \& Hastuti, 2004: 92).

\section{Melakukan Latihan dengan Pengulangan secara Bertahap}

Latihan hendaknya dilakukan secara bertahap, dimulai dari yang sederhana kemudian ke taraf yang lebih kompleks atau sulit. Soal-soal latihan yang diberikan kepada peserta didik hendaknya soal yang masih tergolong mudah, kemudian jika peserta didik dengan soal yang mudah sudah menguasai, maka tingkat kesulitan soal harus di tambah. Jadi soal tersebut sudah di buat sedemikian kompleks sehingga peserta didik benar-benar bisa meningkatkan kemampuannya. Misalnya untuk soal yang kompleks, guru bisa menambahkan akun-akun return dan potongan-potongan harga baik itu dalam pembelian maupun penjualan. Prinsip-prinsip dasar pengerjaan latihan hendaknya telah diberikan kepada anak. 
Pada tahapan ini hal penting yang harus diperhatikan oleh guru PAI adalah terbentuknya proses berpikir yang baik. Proses berpikir merupakan proses yang kompleks dan tidak dapat dilihat secara langsung bagaimana otak bekerja dan informasi diolah. Informasi yang diterima melalui alat indera akan dipersepsikan oleh bagian-bagian yang berfungsi secara khusus. Memahami bagaimana individu mengolah informasi yang masuk kepadanya adalah suatu hal yang cukup rumit. Orang-orang membutuhkan beberapa kajian dan sudut pandang ilmiah untuk dapat memahaminya lebih lanjut. Sebagian besar aktivitas manusia melibatkan apa yang disebut dengan "memori" (Ellis, 1978: 125). Namun aktivitas yang melibatkan memori itu sendiri kadang-kadang tidak disadari dan sering tidak dihiraukan arti pentingnya. Fungsi memori sangat dibutuhkan ketika seseorang melakukan rutinitas, percakapan dengan teman, membaca buku, belajar di kelas, dll. Namun, dalam beberapa kasus otak dan manusia memiliki beberapa ketebatasan ketika diperhadapkan pada peristiwa-peristiwa tertentu. Beberapa uraian di atas merupakan contoh dari berbagai masalah memori. Penekanannya adalah bahwa memori bekan sekedar proses pasif penyimpanan informasi dan penemuan kembali pada saat diperlukan namun memori juga mencakup rekonstruksi sebuah peristiwa.

Memori adalah kemampuan untuk menyimpan apa yang telah pernah dialaminya, tetapi juga termasuk kemampuan untuk menerima, menyimpan, dan menimbulkan kembali apa yang dialami. Pembicaraan mengenai memori memang selalu melalui dua buah sudut pandang, yaitu associationistic, berasal dari seorang pelopor kajian tentang memori, yaitu
Ebbinhaus dan Thorndike, dan information processing yang berasal dari karya ahli psikologi Britania Donald Broadbent. Pendekatan associationistic, menggambarkan bahwa apa yang diperoleh oleh manusia melalui pembelajaran merupakan asosiasi antara peristiwa-peristiwa. Dalam pendekatan ini, proses pembelajaran berlangsung terus menerus. Masalah belajar merupakan masalah bagaimana asosiasi terlupakan karena perjalanan dari waktu ke waktu dan faktor-faktor lain yang mempengaruhi kelupaan asosiasi. Pendekatan ini memandang memori sebagai akibat dari pembelajaran dan memori merupakan hasil dari koneksi mental antara ide dan konsep. Pendekatan information processing, memandang bahwa memori sebagai suatu yang berkaitan dengan arus informasi melalui orang mulai dari proses encode, storage dan retrieval. Hal yang penting dari pendekatan information processing adalah jarak atau perbedaan antara storage dan retrieval. Pendekatan ini memfokuskan lebih banyak kajian ke arah retrieval ketimbang storage, karena pendekatan ini merupakan kunci untuk membuka memori.

Ada tiga proses yang berlangsung di dalam sistem memori manusia. Ketiga proses tersebut adalah encoding, storage, dan retrieval. Encoding yaitu proses pengtransformasian peristiwaperistiwa ke dalam bentuk yang bisa disimpan dan digunakan selama masa tertentu (biasa disebut dengan learning-pembelajaran). Encoding itu sendiri dapat berupa kata-kata, gambar, grafik, fenomena, dll. Lebih lanjut encoding merupakan proses mengalihkan informasi dari bentuk fisik, energi dan lain-lain ke dalam bentuk yang dapat disimpan di dalam memori. Di dalam proses encoding informasi ini dapat terjadi dengan dua 
cara, yaitu; (1) tidak sengaja, yaitu apabila hal-hal yang diterima oleh indranya dimasukkan dengan tidak sengaja kedalam ingatannya. Contohnya konkritnya dapat kita lihat pada anakanak yang umumnya menyimpan pengalaman yang tidak di sengaja, misalnya bahwa ia akan mendapat apa yang diinginkan bila ia menangis keraskeras sambil berguling-guling; dan (2) sengaja, yaitu bila individu dengan sengaja memasukkan pengalaman dan pengetahuan ke dalam ingatannya. Contohnya orang yang bersekolah dimana ia memasukkan segala hal yang dipelajarinya di bangku sekolah dengan sengaja.

Storage disebut juga dengan retensi yaitu proses mengendapkan informasi yang diterima dalam suatu tempat tertentu dan dalam jangka waktu tertentu. Penyimpanan ini sudah sekaligus mencakup kategorisasi informasi sehingga tempat informasi tersimpan sesuai dengan kategorinya. Dalam proses ini, penyimpanan dilakukan untuk peristiwa-peristiwa yang sudah di-encode-kan. Sementara retrieval yaitu sebuah proses pengaksesan, penemubalikan atau pemanggilan kembali informasi yang disimpan di dalam memori untuk digunakan. Proses penemubalikan informasi yang disimpan dalam memori dari sensory memory bersifat langsung dan otomatis.

Memori yang dimiliki oleh peserta didik menjadi krusial bagi keberhasilan metode drill. Ketiadaan memori yang baik dimiliki oleh peserta didik, akan mengakibatkan pembelajaran menjadi tertatih-tatih. Pada langkah ini, hal penting yang harus diperhatikan oleh guru PAI dalam melaksanakan metode drill adalah sebagai berikut:

Meminta peserta didik untuk melakukan latihan dengan pengulangan. Pada bagian ini seorang calon guru atau guru PAI meminta peserta didik untuk melakukan latihan dengan cara berulang. Latihan ini tidaklah sekedar latihan saja, akan tetapi latihan yang menekankan pada adanya proses pengulangan yang dilakuan oleh guru pada peserta didik. Peserta didik diarahkan untuk memahami pembelajaran melalui proses latihan yang berulang-ulang. Pengulangan inilah yang menjadi ciri khas dari metode ini dibanding dengan metode lainnya.

Memberikan prinsip-prinsip dasar pengerjaan latihan. Supaya peserta didik tidak mengalami kesulitankesulitan, maka guru harus memberikan prinsip-prinsip dasar pengerjaan latihan tersebut seperti guru memberikan prinsip bahwa kelompok harta dan beban bertambah ditulis di kolom debit dan jika berkurang ditulis di kolom kredit. Sedangkan jika yang bertambah kelompok akun kewajiban, pendapatan dan modal maka di tulis di kolom kredit dan jika berkurang ditulis di kolom debit. Selama latihan berlangsung, perhatikanlah bagian-bagian mana yang sebagian besar anak-anak dirasakan sulit.

Memantau hasil pekerjaan peserta didik. Ketika peserta didik mengerjakan latihan-latihan melalui pengulangan yang telah dilakukan tersebut, guru PAI hendaknya memantau secara langsung hasil pekerjaan peserta didik. Guru PAI bisa mengecek hasil pekerjaan tiap peserta didik, sehingga guru bisa mengetahui di bagian-bagian mana saja peserta didik mengalami kesulitan. Pemantauan ini menjadi penting untuk proses men-drill-kan materi pembelajaran pada peserta didik. Oleh karena itu penggunaan metode drilli di mana peserta didik memahami pembelajaran melalui proses pengulangan yang berulang-ulang haruslah dipantau oleh guru PAI secara komprehensif. Sebab, bila pengawasan 
kurang bisa jadi para peserta didik melakukannya hanya sekedar saja.

Melatih bagian-bagian yang dipandang sulit.Latihlah bagian-bagian yang dipandang sulit itu lebih intensif. Setelah guru PAI mengetahui di mana letak kesulitan peserta didik, maka guru PAI harus memberikan penjelasan kembali tentang materi yang dianggap sulit oleh peserta didik tersebut serta menambah kuantitas latihan soal-soal sehingga peserta didik bisa lebih memahami materi tersebut. Latihan pada bagian yang dianggap sulit hendaknya lebih intensif, dengan menggunakan alat pelajaran yang dapat membantu mengatasi kesulitan.

Memperhatikan perbedaan individu. Perbedaan individual peserta didik perlu diperhatikan. Pada dasarnya karakteristik peserta didik berbedabeda, sehingga guru harus bisa profesional dalam menangani perkembangan peserta didik ini. Dalam metode pembelajaran drill (latihan keterampilan ini), guru PAI harus bisa membedakan mana peserta didik yang cepat menyerap materi dan mana peserta didik yang agak lambat dalam menyerap materi. Sehingga guru PAI harus melakukan perlakuan yang berbeda pula. Guru PAI bisa memberikan penjelasan berulang-ulang dan juga lebih mengintensifkan peserta didik yang agak lambat ini umtuk sesering mungkin melakukan latihanlatihan soal.

\section{Aplikasi}

Jika suatu latihan telah dikuasai anak-anak, tahap berikutnya adalah aplikasi. Setelah peserta didik mampu memahami bahan pembelajaran dengan baik melalui proses pengulangan dalam latihan tersebut, maka tahap selanjutnya adalah mereka mampu mengaplikasikannya dalam realitas. Peserta didik menerapkan apa yang telah dipahami yang dilakukan dengan berulang-ulang dalam tugas yang telah dipersiapkan oleh guru PAI. Misalnya saja, ketika guru PAI mengajarkan materi al-Qur'an Hadits yaitu menghafal surat al-Ma'un melalui metode drill, maka guru PAI meminta para peserta didik untuk menghafalnya kembali secara individu. Sebab bisa saja pengulangan tadi dilakukan secara bersama-sama, tapi dalam tahap aplikasi para peserta didik telah melakukannya secara individu.

Pada tahap ini seorang guru PAI haruslah melakukan berbagai teknik penting untuk mendukung kesuksesan pembelajaran melalui metode drill tersebut, yaitu; (1) guru PAI meminta peserta didik secara individu untuk mengulangi kembali materi yang telah di-drill-kan tersebut; (2) guru PAI membimbing peserta didik untuk melakukan pengualangan materi tersebut agar memiliki keterampilan yang baik; (3) guru PAI memberikan latihan pada peserta didik terkait dengan pemahaman mereka terhadap materi yang telah di-drill-kan tersebut secara individu maupun bersama-sama; (4) guru PAI mengarakan semua peserta didik untuk melakukan praktek terhadap apa yang telah dipahami setelah melakukan latihan yang berulang-ulang tersebut; (5) guru PAI bersama peserta didik membuat kesimpulan bersama terkait dengan materi yang telah dipahami sesuai dengan indikator dan tujuan pembelajaran.

\section{Melakukan Evaluasi}

Evaluasi ini dilakukan dengan tujuan untuk mengetahui kemampuan peserta didik pada materi. Evaluasi ini sebaiknya dilakukan setiap akhir pertemuan, dengan cara peserta didik harus mengumpulkan hasil latihanlatihan soal yang telah dikerjakan 
peserta didik sehingga guru dapat mengecek pada bagian mana saja peserta didik mengalami kesulitan dan guru bisa membahasnya kembali pada pertemuan minggu berikutnya. Selain itu dengan memberikan tugas untuk peserta didik juga dapat dikatakan evaluasi, jadi setiap satu pokok bahasan selesai, guru memberikan tugas untuk peserta didiknya, supaya peserta didikpeserta didik dapat lebih memahami materi.

Fungsi utama evaluasi adalah menelaah suatu objek atau keadaan untuk mendapatkan informasi yang tepat sebagai dasar untuk pengambilan keputusan. Evaluasi pembelajaran sebagai suatu proses mengumpulkan, menganalisis dan menginterpretasi informasi secaras sistematik untuk menetapkan sejauh mana ketercapaian tujuan pembelajaran.

Evaluasi pembelajaran merupakan evaluasi dalam bidang pembelajaran. Tujuan evaluasi pembelajaran adalah untuk menghimpun informasi yang dijadikan dasar untuk mengetahui taraf kemajuan, perkembangan, dan pencapaian belajar peserta didik, serta keefektifan pengajaran guru. Evaluasi pembelajaran mencakup kegiatan pengukuran dan penilaian. Bila ditinjau dari tujuannya, evaluasi pembelajaran dibedakan atas evaluasi diagnostik, selektif, penempatan, formatif dan sumatif. Bila ditinjau dari sasarannya, evaluasi pembelajaran dapat dibedakan atas evaluasi konteks, input, proses, hasil dan outcome. Proses evaluasi dilakukan melalui tiga tahap yaitu tahap perencanaan, pelaksanaan, pengolahan hasil dan pelaporan.

Pada langkah ini, hal-hal yang perlu untuk dilakukan oleh guru PAI adalah; (1) memberikan tes kepada peserta didik terkait materi pembelajaran yang telah disajikan; (2) memberikan pertanyaan kepada peserta didik terkait penggunaan metode yang dipergunakan apakah berhasil atau tidak; (3) meminta peserta didik untuk memberikan komentar bagaimana pengembangan metode untuk pembelajaran berikutnya.

\section{Tindak Lanjut}

Tindak lanjut dalam penggunaan metode drill sangatlah penting, karena metode ini menekankan pada keterampilan. Apa yang seharusnya dikembangkan anak didik tersebut setelah memiliki keterampilan tertentu yang didapatkan melalui pembelajaran PAI tersebut. Tindak lanjut terhadap kemampuan yang dimiliki oleh guru setelah melakukan latihan sangatlah diperlukan, dan hal itu bisa saja dilakukan di rumah. Pengulangan melalui tindak lanjut ini dapat menjadikan peserta didik melakukan latihan sendiri di luar jam pembelajaran sekolah untuk memperlancaran keterampilan diri sendiri.

Tindak lanjut sangat penting sebagai realisasi dari tahap aplikasi yang sebelumnya telah dilalui oleh peserta didik. Pada tahap ini seorang guru PAI harus melakukan hal berikut; (1) meminta peserta didik untuk melakukan pengulangan di luar kelas terkait materi yang telah dipelajari; (2) menyarankan pada peserta didik untuk terus mengembangkan materi yang telah dipelajari melalui metode drill tersebut.

\section{SIMPULAN}

Metode drill dalam pembelajaran pendidikan agama Islam adalah "suatu cara penyajian bahan pelajaran pendidikan agama Islam dengan jalan melatih peserta didik secara berulangulang dan sungguh-sungguh dalam 
bentuk lisan, tulisan, maupun aktivitas fisik agar peserta didik memiliki ketangkasan atau keterampilan yang tinggi dalam menguasai bahan pelajaran, memperkuat suatu asosiasi atau menyempurnakan suatu keterampilan supaya menjadi permanen".

Secara spesifik ada beberapa hal yang perlu diperhatikan dari metode drill ini dalam pembelajaran pendidikan agama Islam (PAI), yaitu: Pertama, cara penyajian bahan pelajaran pendidikan agama Islam dengan jalan melatih peserta didik secara berulang-ulang dan sungguh-sungguh. Kedua, dalam bentuk lisan, tulisan, maupun aktivitas fisik. Ketiga, agar peserta didik memiliki ketangkasan atau keterampilan yang tinggi dalam menguasai bahan pelajaran, memperkuat suatu asosiasi atau menyempurnakan suatu keterampilan supaya menjadi permanen.

Metode drill wajar digunakan untuk: Pertama, disaat mengajarkan kecakapan motoris dan kedua, di saat mengajarkan kecakapan mental.

Kelebihan metode drill adalah sebagai berikut: (1) pengertian peserta didik lebih luas melalui latihan berulang-ulang; (2) peserta didik siap menggunakan keterampilannya karena sudah dibiasakan; (3) peserta didik memperoleh kecakapan motoris; (4) peserta didik memperoleh kecakapan mental; (5) dapat membentuk kebiasaan dan menambah ketepatan dan kecepatan pelaksanaan; (6) peserta didik memperoleh ketangkasan dan kemahiran dalam melakukan sesuatu sesuai dengan yang dipelajarinya; (7) dapat menimbulkan rasa percaya diri bahwa peserta didik yang berhasil dalam belajar telah memiliki suatu keterampilan khusus yang berguna kelak dikemudian hari; (8) guru lebih mudah mengontrol dan membedakan mana peserta didik yang disiplin dalam belajarnya dan mana yang kurang dengan memperhatikan tindakan dan perbuatan peserta didik saat berlangsungnya pengajaran; dan (9) menghindarkan ketegangan.

Di samping kelebihan yang telah diuraikan di atas, terdapat pula beberapa kelemahan dan sekaligus hal ini menjadi perhatian yang perlu dihindari oleh guru PAI dalam proses pembelajaran pendidikan agama Islam, yaitu: (1) peserta didik cenderung belajar secara mekanis; (2) dapat menyebabkan kebosanan; (3) dapat mematikan kreasi peserta didik; (4) menimbulkan verbalisme; dan (5) menimbulkan penyesuaian secara statis kepada lingkungan.

Langkah-langkah metode drill dalam pembelajaran PAI adalah: (1) asosiasi; (2) menyampaikan tujuan yang hendak dicapai; (3) memotivasi peserta didik; (4) melakukan latihan dengan pengulangan secara bertahap; (5) aplikasi. Jika suatu latihan telah dikuasai anak-anak, tahap berikutnya adalah aplikasi; (6) evaluasi; dan (7) tindak lanjut.

\section{DAFTAR RUJUKAN}

Akbarizan. 2008. Pendidikan Berbasis Akhlak, cet. ke -1. Pekanbaru: Suska Press.

al-Maraghi, Ahmad Musthofa. t.t. Tafsir al-Maraghi, Jilid 29. Beirut: Dar alMaraghi.

Arikunto, Suharsimi dan Cepi Safruddin Abdul Jabbar. 2004. Evaluasi Program Pendidikan Pedoman Teoretis Praktis Bagi Praktisi Pendidikan, cet. 1. Jakarta: Bumi Aksara.

Daradjat, Zakiah, et. al., 1995. Metodik Khusus Pengajaran Agama Islam, cet. 1. Jakarta: Bumi Aksara.

Dimyati dan Mudjiono. 2009. Belajar dan Pembelajaran. Jakarta: PT. Rineka Cipta. 
Djamarah, Syaiful Bahri dan Aswin Zain. 2002. Strategi Belajar Mengajar, cet. 2. Jakarta: Rineka Cipta.

Djamarah, Syaiful Bahri. 2008. Psikologi Belajar, Ed.II. Jakarta: PT. Rineka Cipta.

Ellis, Hendry C., 1978. Fundamental of Learning, Memory and Cognition. Mexico: Wm. C. Brown Company Publishers Dubuque.

Fauzi, Ahmad. 1999. Psikologi Umum. Bandung: CV. Pustaka Setia.

Hamka. 1994. Falsafah Hidup. Jakarta: Pustaka Panjimas.

Hariyanto, "Pengertian dan Tujuan Pembelajaran", www.belajarpsikologi.com, April, 2012.

Muradi, Ahmad, "Pelaksanaan Metode Drill (Latihan Siap) dalam Pembelajaran Bahasa Arab", Jurnal Fikrah, Vol. 5, No. 1, 2006

Nizar, Samsul. 2008. Memperbincangkan Dinamika Intelektual dan Pemikiran HAMKA tentang Pendidikan Islam, cet. 1. Jakarta: Prenada Media Group.

Prawira, Purwa Atmaja, 2012. Psikologi Pendidikan dalam Perspektif Baru. Yogjakarta: Ar-Ruzz Media.

Ramayulis. 2010. Metodologi Pendidikan Agama Islam, cet. ke -6. Jakarta: Kalam Mulia.

Ramayulis. $1990 . \quad$ Metodologi Pengajaran Agama Islam. Jakarta: Kalam Mulia.

Roestiah. 2001. Strategi Belajar Mengajar. Jakarta: Rineka Cipta.

Roestiyah N.K., 1985. Strategi Belajar Mengajar. Jakarta: Bina Aksara.

Sagala, Syaiful. 2009. Konsep dan Makna Pembelajaran untuk Membantu Problematika Belajar dan Mengajar. Bandung: Alfabeta.
Salahuddin, Mahfud. 1987. Metodologi Pengajaran Agama. Surabaya: Bina Ilmu.

Sanjaya, Wina. 2009. Perencanaan dan Desain Sistem Pembelajaran, cet. 2. Jakarta: Kencana Prenada Media Group.

Sardiman A.M., Interaksi dan Motivasi Belajar Mengajar. 2011. Jakarta: PT. Raja Grafindo Persada.

Sarwono, Sarlito Wirawan. 2010. Pengantar Psikologi Umum. Jakarta: Rajawali Pers.

Setyosari, Punaji. 2010. Metode Penelitian Pendidikan dan Pengembangan, cet. 1. Jakarta: Kencana Prenada Media Group.

Shaleh, Abdul Rachman, Pendidikan Agama Islam dan Pembangunan Watak Bangsa, Jakarta: RajaGrafindo Persada, 2006, ed. 1

Shaleh, Abdul Rahman. 2006. Pendidikan Agama \& Pembangunan Watak Bangsa, Jakarta: Rajawali Perss.

Shihab, Quraish M., Tafsir al-Mishbah. 2012. Pesan, Kesan dan Keserasian al-Qur'an Volume 14, cet. ke -5. Jakarta: Lentera Hati.

Soemanto, Wasty. 2006. Psikologi Pendidikan, Edisi Revisi. Jakarta: PT. Rineka Cipta.

Solso, Robert L., et. al., 2008. Psikologi Kognitif, Edisi ke-8. Jakarta: Erlangga.

Winkel, W.S. dan M.M. Sri Hastuti. 2004. Bimbingan dan Konseling di Institusi Pendidikan. Yogyakarta: Media Abadi.

Zuhairini, et. al., 1983. Metodik Khusus Pendidikan Agama. Surabaya: Usaha Nasional. 